\title{
Design and Performance Evaluation of a Heat Pump System Utilizing a Permanent Dewatering System
}

\author{
Seung-Hoon Park ${ }^{1}\left(\mathbb{D}\right.$, Yong-Sung Jang ${ }^{2}$ and Eui-Jong Kim ${ }^{1, * \mathbb{D}}$ \\ 1 Department of Architectural Engineering, INHA University, Inha-ro 100, Michuhol-gu, Incheon 22212, Korea; \\ pshtony@inha.edu \\ 2 GS E\&C Research Institute, Baegok-daero 388, Cheoin-gu, Youngin, Gyeonggi-do 17130, Korea; \\ ysjang02@gsenc.com \\ * Correspondence: ejkim@inha.ac.kr; Tel.: +82-32-860-7589
}

check for updates

Citation: Park, S.-H.; Jang, Y.-S.; Kim, E.-J. Design and Performance Evaluation of a Heat Pump System Utilizing a Permanent Dewatering System. Energies 2021, 14, 2273. https://doi.org/10.3390/en14082273

Academic Editor:

Fernando Lopez-Rodriguez

Received: 27 March 2021

Accepted: 15 April 2021

Published: 18 April 2021

Publisher's Note: MDPI stays neutral with regard to jurisdictional claims in published maps and institutional affiliations.

Copyright: (c) 2021 by the authors. Licensee MDPI, Basel, Switzerland. This article is an open access article distributed under the terms and conditions of the Creative Commons Attribution (CC BY) license (https:// creativecommons.org/licenses/by/ $4.0 /)$.

\begin{abstract}
The earth provides a vast resource of groundwater from aquifers a few meters beneath the surface. Thus, buildings that use underground space must be equipped with dewatering wells to drain the permeated groundwater to the sewage pipelines to ensure the structural stability of the building. Although the inflowing groundwater temperatures and flow rates are stable enough for groundwater to be used as an energy source, $79 \%$ of the permeated groundwater is discarded through the sewers, generating significant sewerage expenses. This study introduced a novel heat exchanger module to utilize the permeated groundwater as an unused energy source using heat pumps, and the performance of the system was evaluated by TRNSYS simulations. First, the sizing of the unit heat exchanger module was proposed according to the mean inflow rate of the permeated groundwater. Second, the heat pump system was configured using multiple modules in the sourceside loop. Finally, the performance of the proposed heat pump system was compared with that of a conventional air source heat pump using realistic load and temperature profiles. This preliminary study demonstrated interesting performance results, with a coefficient of performance for heating that was higher than that of a conventional heat pump system by 0.79 . The results show the potential utilization of the systems for a construction project requiring large-scale underground spaces, where abundant groundwater is available.
\end{abstract}

Keywords: building energy; groundwater; heat pump system; permanent dewatering; unused energy source

\section{Introduction}

Upon the adoption of the Paris Agreement by the United Nations Climate Change Conference (UNCCC) in 2015, countries worldwide agreed to limit the increase in the average atmospheric temperature to below $2{ }^{\circ} \mathrm{C}$ by cooperating to reduce their respective greenhouse gas emissions [1]. Korea, ranking seventh in greenhouse gas emissions, set a goal to reduce emissions by $37 \%$ of the current emissions by 2030 and has developed and implemented diverse regulations for industries, transportation, buildings, and the public sector. In particular, buildings, occupying 30\% of the primary annual energy consumption, exhibit great potential for reducing emissions [2,3]. Thus, the Korean government has encouraged the installation of new and renewable energy systems to minimize the consumption of fossil fuels and intends to implement the mandatory installation of these systems for all types of buildings by 2030 .

According to the regulation of the Seoul metropolitan government [4], 5-15\% of the energy consumption of new buildings constructed before the year 2025 will be required to utilize alternative energy through new and renewable energy systems. Currently, new buildings frequently adopt new and renewable energy systems, instead of existing systems using fossil fuels, for the operation of public spaces, such as elevators or underground parking lots. However, under the governmental regulations that encourage the introduction 
of systems comprising solar energy, geothermal heat pumps, and fuel cells, which require a considerable initial investment, construction companies in the private sector have also attempted unprecedented approaches to secure unused and economical sources of energy.

The unused energy system application for buildings is now promising solutions to reduce greenhouse gas emissions. By combining water-source energy such as groundwater, wastewater, river, and lakes with existing heat pump systems, the system efficiency can be increased resulting in lower greenhouse effects $[5,6]$. The groundwater flowing into the dewatering well exhibits a stable annual temperature range of $15-20{ }^{\circ} \mathrm{C}$, which is attributable to the high thermal capacity of the surrounding earth. Thus, if the underground inflow is secured, it could be exploited as a source of energy rather than contributing to the maintenance costs of the building.

Studies from the past 10 years regarding the exploitation of groundwater and sewage water are summarized in Table 1. These studies have proposed systems such as groundwater heat pumps (GWHPs), wastewater source heat pumps (WWHPs), and sewage water heat pump (SWHP) systems to take advantage of these untapped energy sources. The GWHP system is a type of ground source heat pump (GSHP) system, for which holes are drilled to a depth of 300-500 m underground to install wells that act as a heat source for the heat pump [7]. WWHP and SWHP systems utilize residential wastewater through heat exchanger loops that are installed on the sewage pipeline to recover the waste heat $[8,9]$. Water storage in reservoirs or ponds located near a building can be another potential source of unused energy $[10,11]$.

Table 1. Review of research on unused energy source heat pump systems.

\begin{tabular}{|c|c|c|}
\hline Authors & Heat Source & Source Side Loop Type \\
\hline Luo et al., 2020 [12] & Groundwater & Injection and production well \\
\hline Zhang et al., 2020 [10] & Lake water & Heat exchanger \\
\hline Hervás-Blasco et al., 2020 [8] & Greywater & Greywater storage tank and heat exchanger \\
\hline Song et al., 2019 [13] & Groundwater & $\begin{array}{l}\text { Standing column well (SCW), injection and production } \\
\text { well, forced external circulation SCW }\end{array}$ \\
\hline Kastrinos et al., 2019 [7] & Groundwater & Standing column well \\
\hline Qin \& Hao, 2017 [9] & Sewage water & Free-flow-channel heat exchanger \\
\hline Zhou et al., 2013 [14] & Groundwater & Injection and production well \\
\hline Shen et al., 2012 [15] & Wastewater & Wastewater storage tank and heat exchanger \\
\hline Ferguson, 2012 [16] & Groundwater & Injection and production well \\
\hline Cho \& Yun, 2011 [11] & Lake water & Brine water loop heat exchanger \\
\hline Russo et al., 2011 [17] & Groundwater & Injection and production well \\
\hline Nam \& Ooka, 2010 [18] & Groundwater & Injection and production well \\
\hline
\end{tabular}

The WWHP and SWHP systems exhibit higher temperatures due to the hot water from the sources of waste heat [12] and come with the disadvantage of heat exchanger fouling, which necessitates the installation of ancillary equipment for maintenance [19]. Conversely, heat pump systems with the heat exchanger attached to the dewatering wells require less initial investment and benefit from stable groundwater temperatures of approximately $15-20{ }^{\circ} \mathrm{C}$, and it is also possible to avoid the fouling problem by using uncontaminated groundwater. The GWHP system can provide a better and more stable performance than an air source heat pump (ASHP) under equivalent conditions $[20,21]$ and is more economical in terms of maintenance with a longer expected lifespan of the system [12]. The standing column well (SCW) ground heat exchanger coupled heat pump system is one of the wellknown forms of the GWHP system. However, the system requires a high initial investment for underground drilling of more than $300 \mathrm{~m}$ to install a groundwater well.

In Korea, the demand for large-scale residential apartments is substantial, particularly in areas that are characterized by shallow groundwater aquifers at 5-20 m below the ground surface [22]. The underground spaces in buildings in urban areas are typically utilized for underground parking lots or commercial facilities, so, dewatering wells and drainage equipment (e.g., drain pump, level gauge) are added during the initial excavation 
phase of construction to reject the inflowing groundwater. These systems are expected to operate throughout the lifespan of the building, they are called permanent dewatering (PD) systems. Since the PD systems operate continuously, buildings with large amounts of groundwater inflow incur high managerial costs owing to sewage treatment.

To use the hydrothermal energy of the PD systems, thermal performance of the PD system should be defined. However, research regarding PD systems similar to the one proposed in the present study is yet to be reported. In the present study, a heat pump system to utilize the PD system was proposed and analyzed, named by permanent dewatering heat pump (PDHP) system. The cooling/heating performance of the system was analyzed through varying the inflow rate of the groundwater to take advantage of this unused source of energy.

The challenge and contribution of the present study is to figure out the thermal performance of PDHP system, to answer the following two questions:

1. How much energy can be transferred by PD modules under variable amounts of groundwater inflow?

2. To what extent can the COP of the PDHP be improved compared with that of an ASHP under equivalent conditions?

The TRNSYS, Transient system simulation program [23], which is a well-known energy analysis tool for building energy systems, was employed to analyze the PDHP system, and compare the PDHP system performance with conventional ASHP system. The review of groundwater resources to utilize the PDHP system and its detailed description were presented in Section 2. The simulation-based PDHP system design method was presented in Section 3. The results of the design capacity $(\mathrm{kW})$ of a single PD module and PDHP system, and also the comparison with ASHP were presented in Section 4.

\section{Permanent Dewatering Heat Pump System}

Figure 1 represents the groundwater level data for each observed location in Seoul from 2016 to 2019 [24]. From data of the 6-13 observatories of each district, it was revealed that the deepest groundwater depth was approximately $18 \mathrm{~m}$ and the average value was $9.3 \mathrm{~m}$ for all locations, therefore, all buildings that utilize underground space must install a PD system. According to the statistics [25], on the use of the inflow of groundwater prepared by the city of Seoul, most of the groundwater flowing into the PD system is wasted as an unused source of energy.
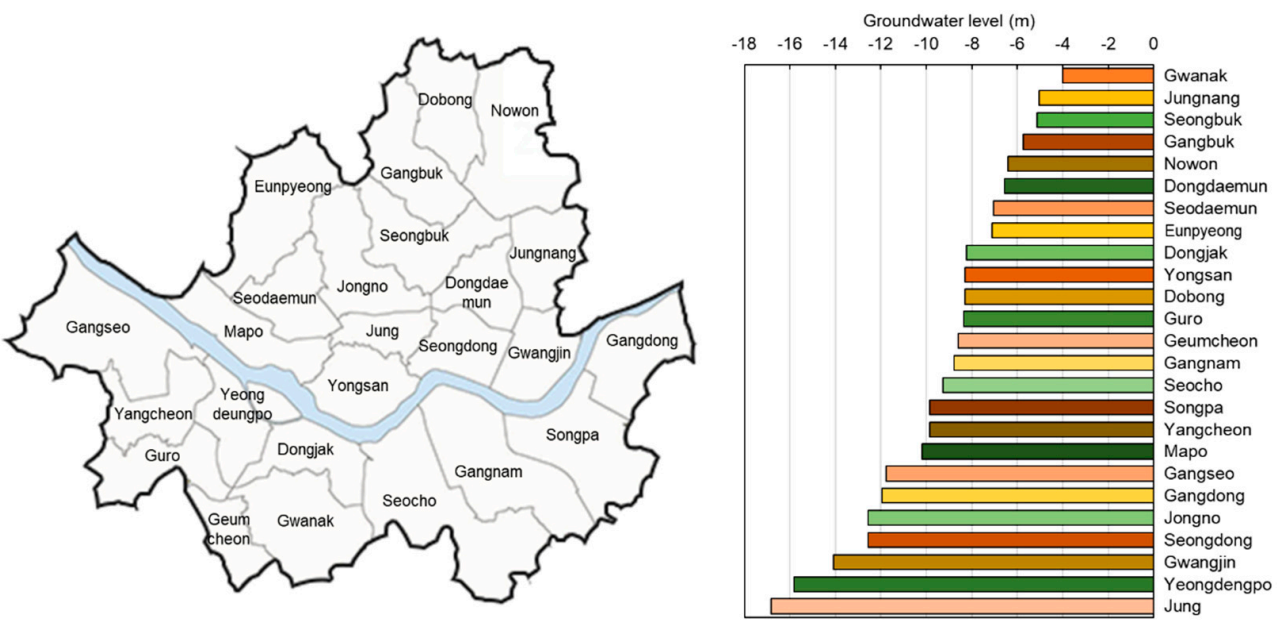

Figure 1. The depth of the groundwater levels observed in the districts of Seoul, South Korea.

As illustrated in Figure 2, the average daily amount of groundwater inflow, observed for 1650 independent buildings in 2018 in Seoul, was 52 tons per day, of which 79.1\% was discharged into the sewerage system. Among the remaining $20.9 \%, 12.3 \%$ of the 
groundwater inflow was consumed within the building, with most of the water wasted except in buildings using a well-type borehole heat exchanger.

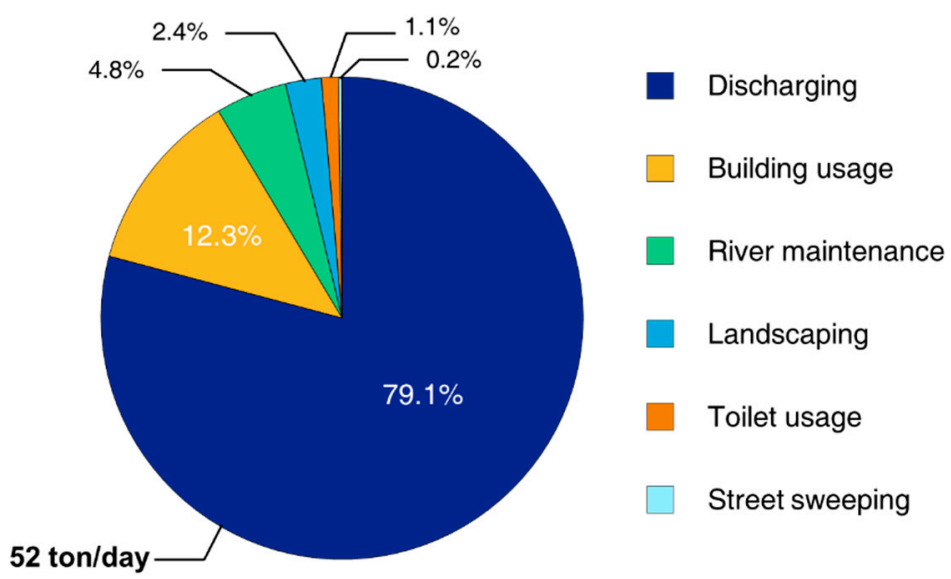

Figure 2. Utilization percentage of the inflowing groundwater in buildings (Seoul, South Korea).

A large-scale apartment complex in an urban area would typically install several collecting wells, as shown on the left in Figure 3, to drain the groundwater seeping through the underground walls of the building. This groundwater could be used as a source of heat by installing additional equipment capable of collecting or discharging heat energy within the existing collection wells. On the right in Figure 3 is a visual design of the PD module proposed in the present study for the exploitation of groundwater as a heat source. The PD module comprises two containers separated by a baffle: a discharging container corresponding to the existing well and a heat exchanger (HX) container. This PD module prototype uses a coil-type heat exchanger, where the design of this type and mechanism of the heat exchanger is currently in progress.

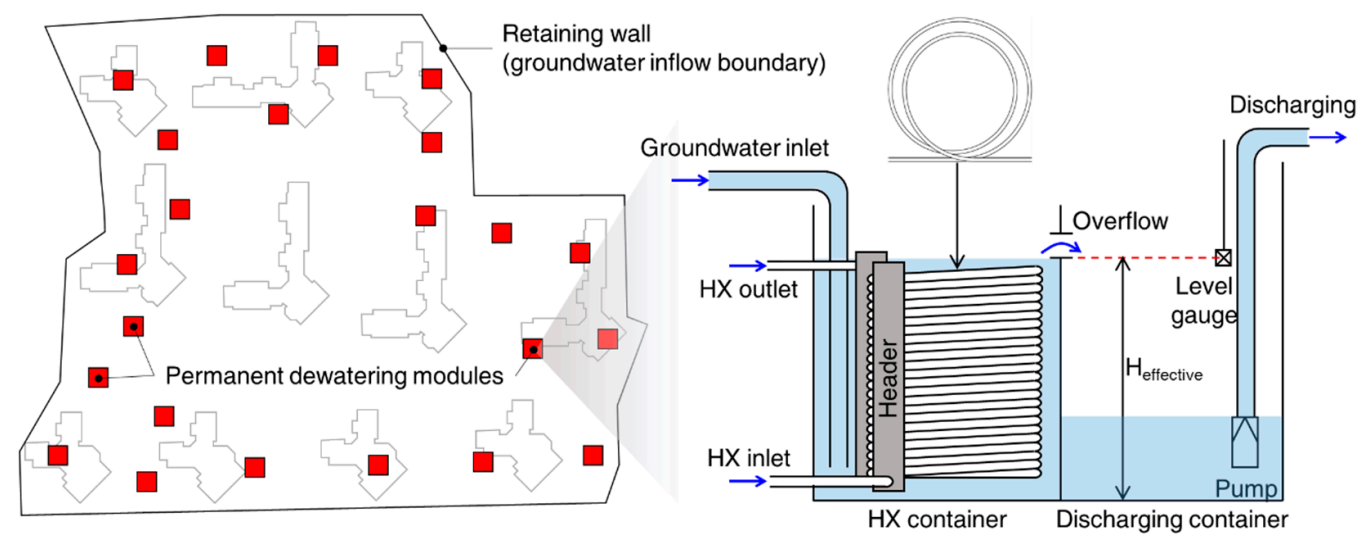

Figure 3. Schematic of the permanent dewatering module (prototype).

The discharging container, installed to drain the groundwater, is a water tank of $1.2 \times 1.2 \times 1.5 \mathrm{~m}$ or $1.4 \times 1.4 \times 1.5 \mathrm{~m}$, with a water gauge installed at the height of $1.2 \mathrm{~m}$ from the bottom to trigger the pump to drain the water when it exceeds the predetermined level. The HX container, which has the same size as the discharging container, comprises a pipe with an inlet and outlet installed on the side of the container into which the groundwater flows, with water level gauge and overflow outlet installed at the same level on the other side, through which the HX container is connected to the discharging container. Irrespective of the operation of the drainage pump, the HX container should be completely filled with water for better heat exchange rates.

The coil-type HX container has a bundle of dual coils that are connected to the inlet/outlet headers in parallel, with the coils equally spaced to attain more surface area 
for efficient heat exchange. The length of each coil varies according to the size of each module, and the coil pitch is $2 \mathrm{~cm}$ so that a total of 60 coils can be installed at the height of the overflow. Unlike the case of a standard thermal storage tank, a sufficient amount of continuously flowing groundwater is necessary for its exploitation as a heat source when collected in small water tanks of $1.2 \times 1.2 \times 1.5 \mathrm{~m}$ and $1.4 \times 1.4 \times 1.5 \mathrm{~m}$. Thus, the utilization of a larger water tank for multiple buildings, such as apartment complexes, would be advantageous over utilization of individual tanks in each building. A detail size and specification of the PD modules are presented in Table 2.

Table 2. Specification of the prototype module pertaining to the HX container.

\begin{tabular}{cccc}
\hline PD Module & $\mathbf{1 . 2} \times \mathbf{1 . 2} \times \mathbf{1 . 5} \mathbf{~ m}$ & $\mathbf{1 . 4} \times \mathbf{1 . 4} \times \mathbf{1 . 5} \mathbf{~}$ & Unit \\
\hline Floor area & 1.44 & 1.96 & $\mathrm{~m}^{2}$ \\
Coil length & 7.250 & 8.515 & $\mathrm{~m}$ \\
Effective height & \multicolumn{2}{c}{1.2} & $\mathrm{~m}$ \\
Coil diameter (inner/outer) & \multicolumn{3}{c}{$0.012 / 0.016$} \\
Coil pitch & 0.02 & $\mathrm{~m}$ \\
Number of coils & 60 & $\mathrm{~m}$ \\
\hline
\end{tabular}

The entire residential complex presented in Figure 3 shares the underground space for parking, securing a sufficient amount of groundwater because of its extensive border. Table 3 represents the inflow of groundwater into residential complexes within Seoul and the average amount flowing into a single collecting well, with a total of 20-22 collecting wells installed for the operation of each drainage system. The total inflow of groundwater is the sum of the average amount of water flowing into each collecting well, which was found to be 24.5 ton/day.

Table 3. Measured groundwater inflow rates for eight apartment sites.

\begin{tabular}{|c|c|c|c|c|c|c|}
\hline \multirow{2}{*}{ Site } & \multirow{2}{*}{ District } & \multirow{2}{*}{$\begin{array}{c}\text { Number of Apartment } \\
\text { Buildings }\end{array}$} & \multicolumn{2}{|c|}{ Total Groundwater Flow Rate } & \multicolumn{2}{|c|}{$\begin{array}{c}\text { Groundwater Flow Rate per } \\
\text { Dewatering Well }\end{array}$} \\
\hline & & & Ton/Day & Lpm & Ton/Day & Lpm \\
\hline A & Mapo & 12 & 25 & 17 & 1.1 & 0.8 \\
\hline B & Eunpyeong & 3 & 224 & 156 & 9.9 & 6.9 \\
\hline $\mathrm{C}$ & Seongbuk & 17 & 346 & 240 & 15.4 & 10.7 \\
\hline $\mathrm{D}$ & Seocho & 5 & 370 & 257 & 16.4 & 11.4 \\
\hline E & Seocho & 7 & 728 & 506 & 32.3 & 22.4 \\
\hline $\mathrm{F}$ & Jung & 14 & 764 & 531 & 33.9 & 23.5 \\
\hline G & Jongno & 14 & 898 & 624 & 38.2 & 26.5 \\
\hline $\mathrm{H}$ & Hanam & 12 & 1100 & 764 & 48.8 & 33.9 \\
\hline \multicolumn{3}{|c|}{ Average } & 557 & 387 & 24.5 & 17.0 \\
\hline
\end{tabular}

\section{Simulation-Based PDHP System Analysis}

In the present study, the PDHP system employing the PD module was simulated assuming a daily average inflow of groundwater of 24.5 ton/day (17 Lpm) flowing into the prototype PD modules of $1.2 \times 1.2 \times 1.5 \mathrm{~m}$ and $1.4 \times 1.4 \times 1.5 \mathrm{~m}$. As previously discussed, the proposed prototype of the PD module was devised as a water-source heat pump system with the heat exchanger attached to the existing system built to drain the groundwater to the sewerage system. As presented in Figure 4, the PDHP system consists of a building, a heat pump, and a PD module, with the two-loop systems configured on both sides of the heat pump. The blue text in Figure 4 indicates an index representing the temperature and flow rate at each point of the system, with EST, LST, G. W, and PDHX signifying the entering source temperature, leaving source temperature, groundwater, and PD heat exchanger, respectively. 


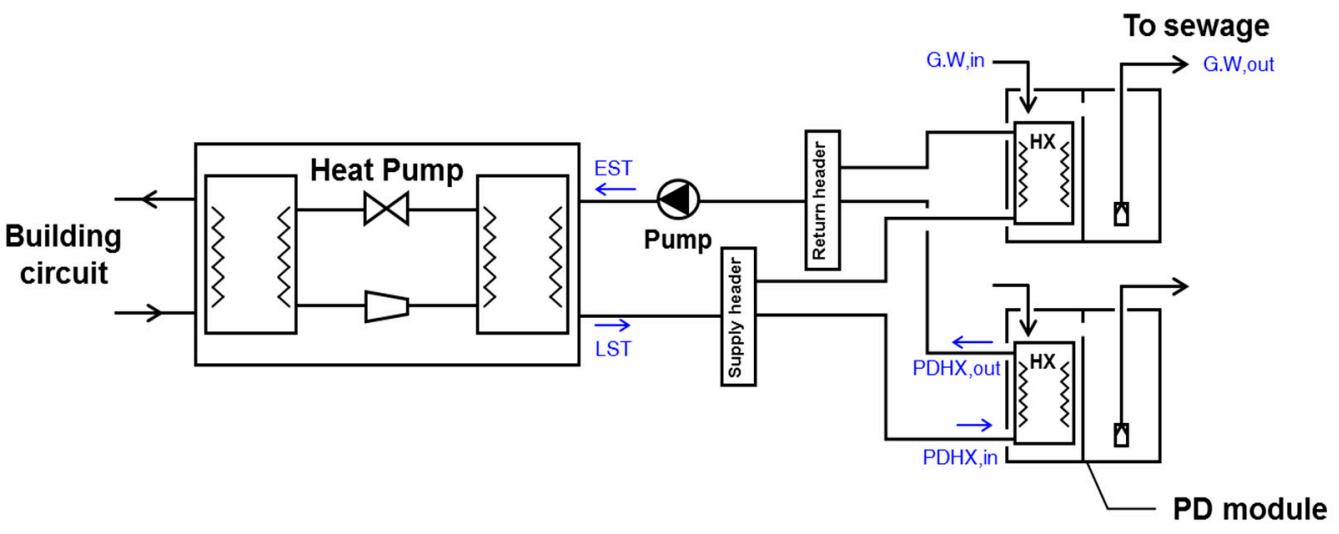

Figure 4. Source-side configuration of the permanent dewatering coupled heat pump (PDHP) system.

The analyses were carried out through simulations to design the PDHP system employing the PD module and appraise its performance. In the design, the building load profile consisted as the cooling dominant case, and the inflow of water was of high temperature, which were used to calculate the capacity of the PD module conservatively. In contrast, the building load profiles of the cooling and heating capacities were similar to each other, and the temperature of the original inflow of water was reflected to appraise the performance under ordinary conditions. The different conditions employed for the design and evaluation of performance are presented in Table 4.

Table 4. Different simulation conditions for PDHP system design and performance estimation.

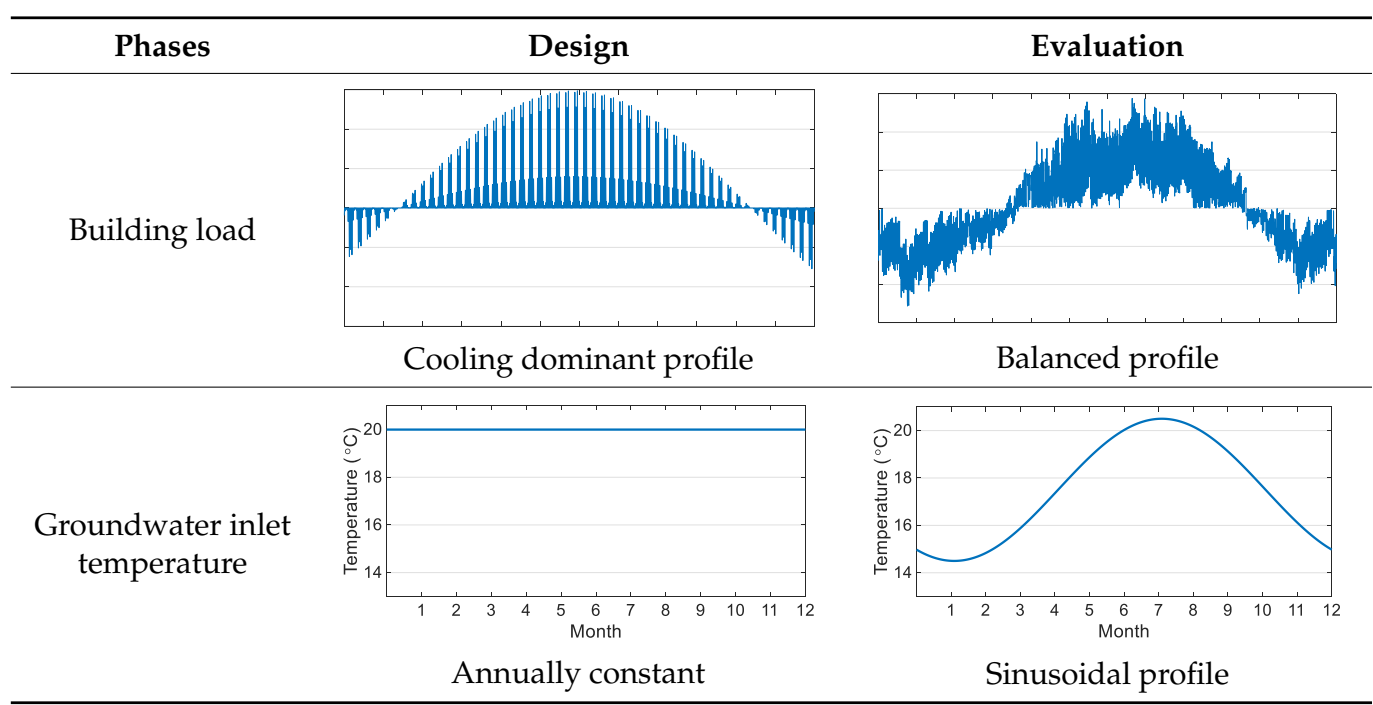

The PD module was connected to the heat pump to determine the applicability of the PD module as a heat source. The system capacity was analyzed by varying the amount of groundwater inflow and the circulated flow rate of the heat pump under the building load conditions where the cooling was dominant. TRNSYS 17, a dynamic energy simulation program, was employed for the analyses, and Type-534 coiled-type HX tank in the TRNSYS TESS library was used for the simulation of the prototype PD module. The flow rate of the total circulation on the source side of the heat pump was assumed to be distributed to each PD module according to Equation (1), configuring multiple modules in parallel with varying inflow of groundwater.

$$
\dot{m}_{\mathrm{PDcoil}}=\frac{\dot{m}_{\mathrm{HP}, \mathrm{S}}}{N_{\mathrm{PD}}}
$$


where $\dot{m}_{\mathrm{PDcoil}}$ and $\dot{m}_{\mathrm{HP}, \mathrm{S}}$ indicate the flow rate of the PDHX in each PD module and the total source-side flow rate of the heat pump, Lpm, respectively, and $N_{\mathrm{PD}}$ represents the number of PD modules.

The design of the heat pump system should be configured such that the EST of the heat source side is kept within the temperature capacity of the heat pump. For a GSHP, the maximum extent of the designed EST ( $\mathrm{EST}_{\text {set }}$ ) on the heat source side, capable of being supported by the capacity of the heat pump, is generally set at $30^{\circ} \mathrm{C}$, which was also used for the PDHP system proposed in the present study.

Figure 5 represents the load profile of a building employed for the design of the PDHP system. The annual profile with the capacity of $100 \mathrm{~kW}$ for the operations of cooling and heating, with the cooling operation dominant $88.3 \%$ of the time, was used. The cooling and heating loads are expressed as $(+)$ and $(-)$, respectively. The building load on Figure 5 was converted into the heat pump load $\left(Q_{\mathrm{HP}}\right)$ by the heat pump COPs, and the $\Delta T_{\mathrm{HP}, \mathrm{S}}$ (=LST - EST) of the heat pump was set to vary according to the constant flow rate $\left(\dot{m}_{\mathrm{HP}, \mathrm{S}}\right)$ (constant $\dot{m}_{\mathrm{HP}, \mathrm{S}}$ cases), also the $\dot{m}_{\mathrm{HP}, \mathrm{S}}$ was set, such that the $\Delta T_{\mathrm{HP}, \mathrm{S}}$ would be maintained at approximately $5{ }^{\circ} \mathrm{C}$ (constant $\Delta T_{\mathrm{HP}, \mathrm{S}}$ cases) using Equation (2). A total of 10 heat pumps were installed to maintain the temperature difference at the interval of a partial load at $\Delta T_{\mathrm{HP}, \mathrm{S}} \approx 5{ }^{\circ} \mathrm{C}$, by which the operation of each pump was assumed to correspond the partial building load of $10 \mathrm{~kW}$.

$$
Q_{\mathrm{HP}}=\dot{m}_{\mathrm{HP}, \mathrm{S}} c_{p}(\mathrm{LST}-\mathrm{EST})
$$

Based on the tabulated data provided by a heat pump manufacturer, the coefficient of performance (COP) was determined according to EST, as expressed in Equation (3). The performance indicators such as $\alpha$ and $\beta$ describe the COP variation as shown in Figure 6, and they are given in Table 5.

$$
\left\{\begin{array}{l}
\mathrm{COP}_{\mathrm{C}}=\alpha_{0}+\alpha_{1} \mathrm{EST}+\alpha_{2} \mathrm{EST}^{2} \\
\mathrm{COP}_{\mathrm{H}}=\beta_{0}+\beta_{1} \mathrm{EST}+\beta_{2} \mathrm{EST}^{2}
\end{array}\right.
$$

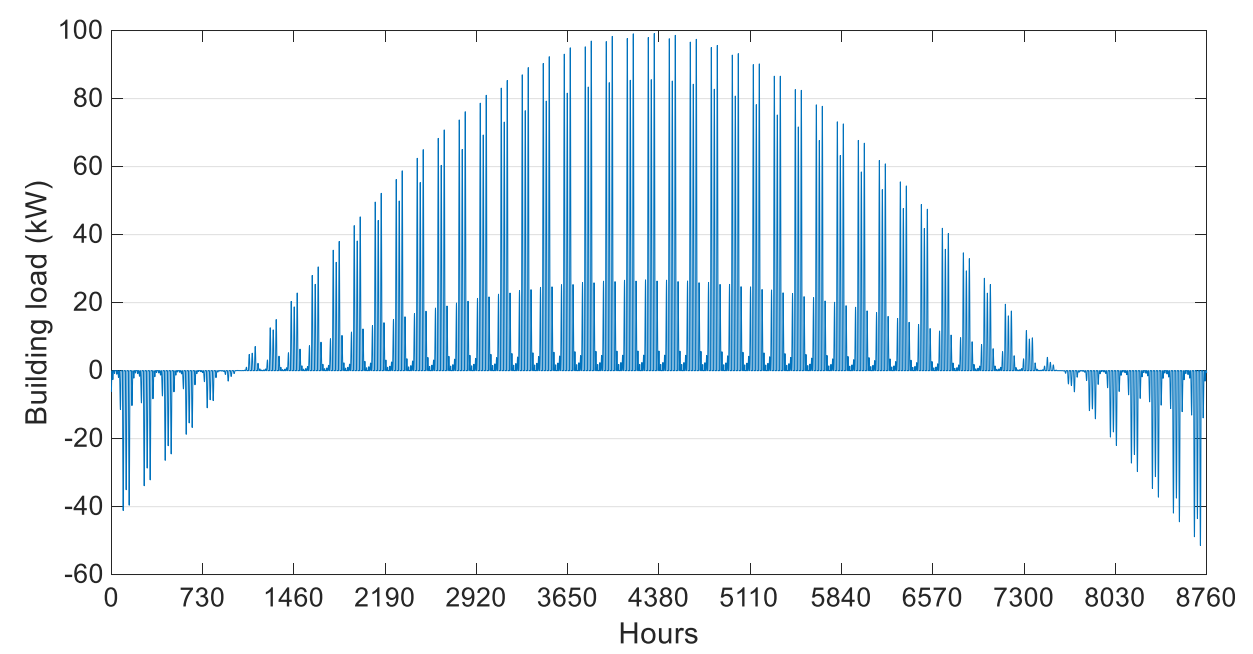

Figure 5. Annual building load profile (cooling (+) and heating (-)). 


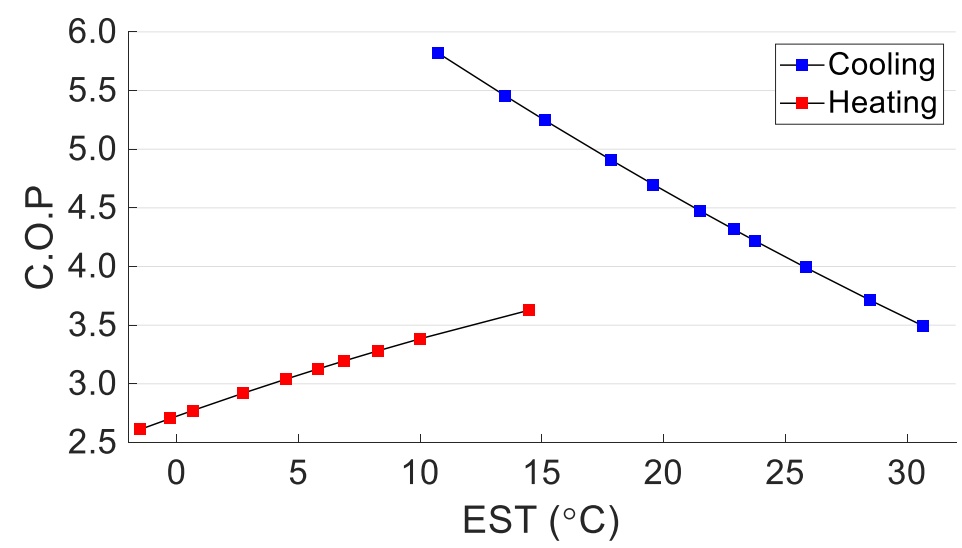

Figure 6. Heat pump EST-COP curve for heating and cooling operations.

Table 5. Comparison of the heat pump performance data for the ASHP-PDHP simulation.

\begin{tabular}{ccc}
\hline $\mathbf{i}$ & $\alpha_{\boldsymbol{i}}$ & $\beta_{\boldsymbol{i}}$ \\
\hline 0 & 7.369 & 2.724 \\
1 & -0.114 & 0.074 \\
2 & 0.0009 & -0.0008 \\
\hline
\end{tabular}

The source-side temperature of the PDHP system is much more stable and lower than the outdoor air temperature. The groundwater temperature remains at $15-20{ }^{\circ} \mathrm{C}$ annually, as shown in Figure 7, while the outdoor air temperature varies from -10 to $35{ }^{\circ} \mathrm{C}$, as shown in Figure 8a. Thus, higher heat pump COPs for the PDHP are expected compared with those of a conventional ASHP system. The sinusoidal groundwater temperatures in Figure 7 were used for the comparison simulation between the PDHP and ASHP, as mentioned earlier.

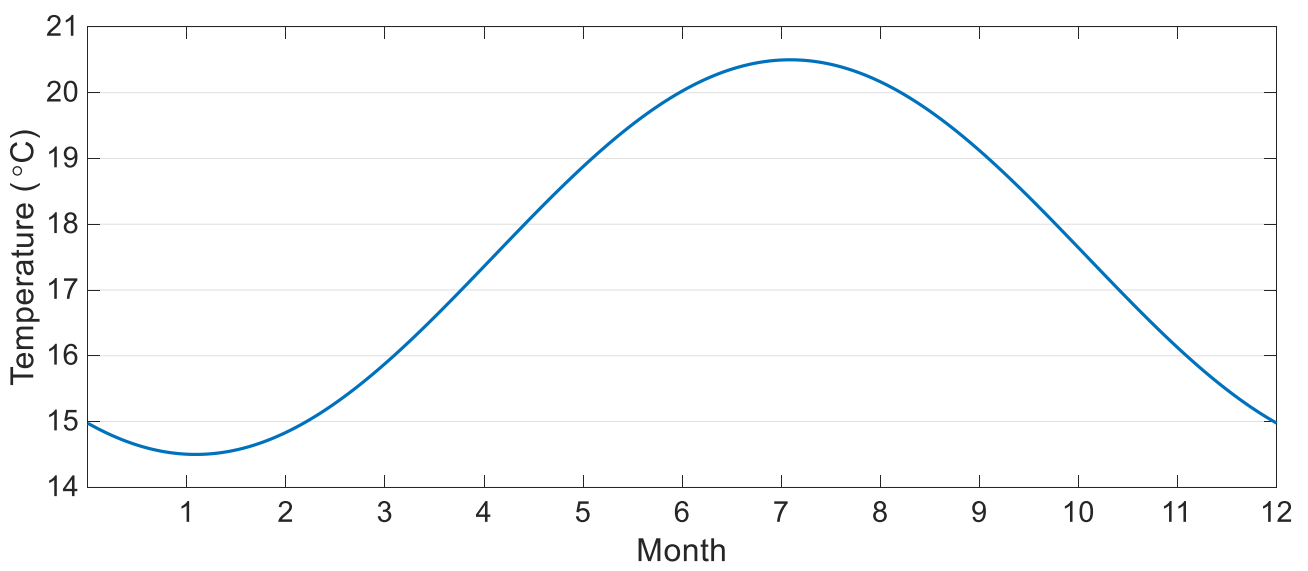

Figure 7. Annual profile of the inlet groundwater temperatures of the flow to the PDHX container.

The simulations of the present study aimed at comparing the system performances, particularly focusing on the heat pump COP. The $\alpha$ and $\beta$ in Table 5 were substituted for the corresponding terms in Equation (3) to model the heat pump so that the ASHP and PDHP would use identical heat pumps, where the ASHP and PDHP were assumed to represent an outdoor unit and a PD unit of $1.4 \times 1.4 \times 1.5 \mathrm{~m}(1.4$ PD module), respectively. The simulation of each pump was carried out to compare the pumps' annual performance by varying the temperature differences on the side of the heat source.

Figure 8 shows the annual hourly outdoor temperatures extracted from the Seoul TRY weather data and the test building load of $6 \mathrm{~kW}$. The pattern of the building load of a 
typical residential house in Korea, having a floor area of $124 \mathrm{~m}^{2}$ and set temperatures of $26^{\circ} \mathrm{C}$ and $20^{\circ} \mathrm{C}$ for cooling/heating, was used.

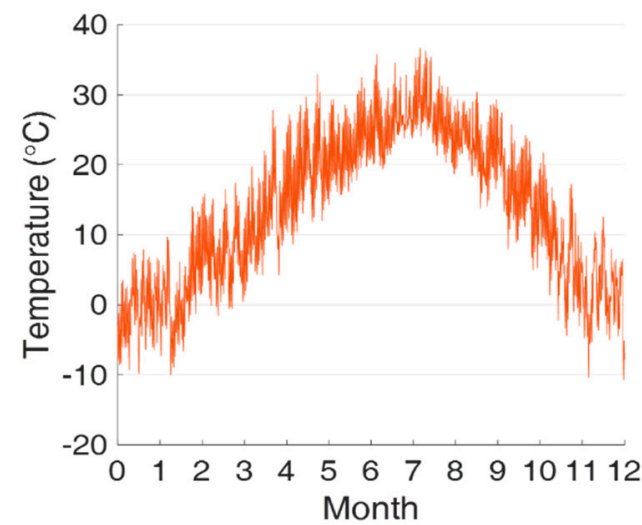

(a)

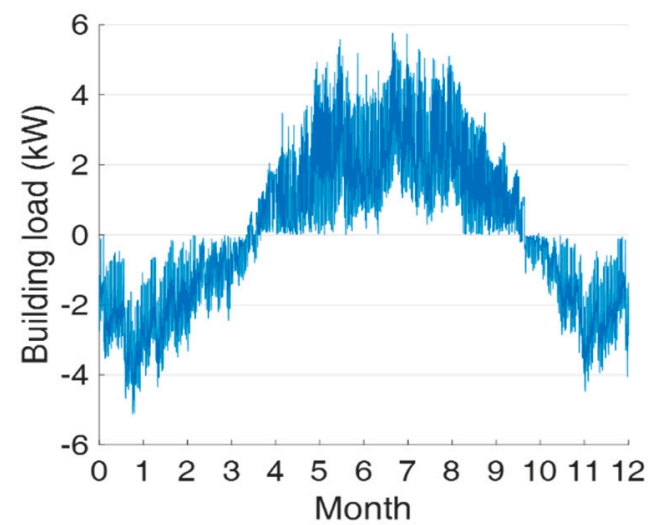

(b)

Figure 8. Seoul TRY outdoor weather data (a) and $6 \mathrm{~kW}$ building load (b).

\section{Simulation Results and Discussions}

\subsection{Design Capacity of a Single PD Module}

The capacity of the prototype PD module was derived through the iterative procedure presented in Figure 9. As illustrated in Figure 4, the TRNSYS 17 template was modeled and simulated with a single PD module in the loop on the heat source side of the heat pump, and the cutoff range of the building load with a capacity of $100 \mathrm{~kW}$ was adjusted until the peak value of the maximum EST $\mathrm{PDHX}_{\text {(EST }}$ peak $)$ reached the 'Best fit' for $\mathrm{EST}_{\text {set }}$. Through such iterations equalizing EST $_{\mathrm{PDHX}}$ with $\mathrm{EST}_{\text {set }}$, the peak value of the building load $\left(Q_{\mathrm{b}, \text { peak }}\right)$, equivalent to the capacity of the PD module, could be obtained. The iterative procedure presented in Figure 9 was also applied to the simulation for design of multiple PDHP system. The method proposed by Park and Kim [26] was used for the detailed simulation-based iterative calculation.

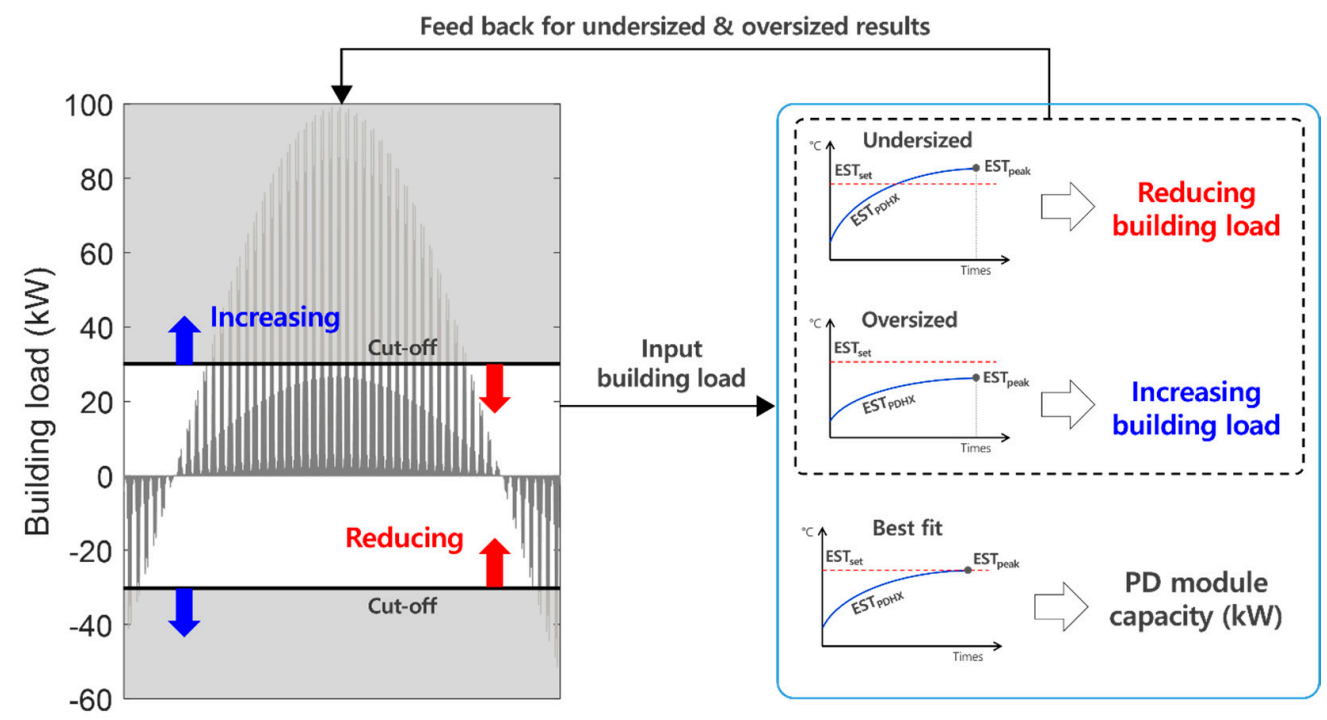

Figure 9. Sizing procedure for simulation-based PDHP system design.

Figure 10 and Tables 6 and 7 present the capacity results of 1.2, and 1.4 PD modules. In order to investigate the sizing results of the PD modules, two different cases, such as a constant heat pump source-side temperature difference $\left(\Delta T_{\mathrm{HP}, \mathrm{S}}=\mathrm{LST}-\mathrm{EST}\right)$ and a constant flow rate $\left(\dot{m}_{\mathrm{HP}, \mathrm{S}}\right)$ are tested. The results for the cases are given in Figure 10, and the details are also listed in Tables 6 and 7 . Table 6 presents the results for a constant 
heat pump $\Delta T_{\mathrm{HP}, \mathrm{S}}=5.4^{\circ} \mathrm{C}$, while Table 7 presents the results for the constant heat pump source-side flow rates, $\dot{m}_{\mathrm{HP}, \mathrm{s}}: 21.8 \mathrm{Lpm}$ (1.2 PD module) and 23.2 Lpm (1.4 PD module). The sizing $(\mathrm{kW})$ results for single 1.2 and 1.4 PD modules are presented according to the groundwater inflow variations, 5-60 Lpm, based on the sizing procedure presented in Figure 9 for both the constant $\Delta T_{\mathrm{HP}, \mathrm{S}}$ and $\dot{m}_{\mathrm{HP}, \mathrm{S}}$ cases. All of the values that appear in this section were obtained at the peak building load.
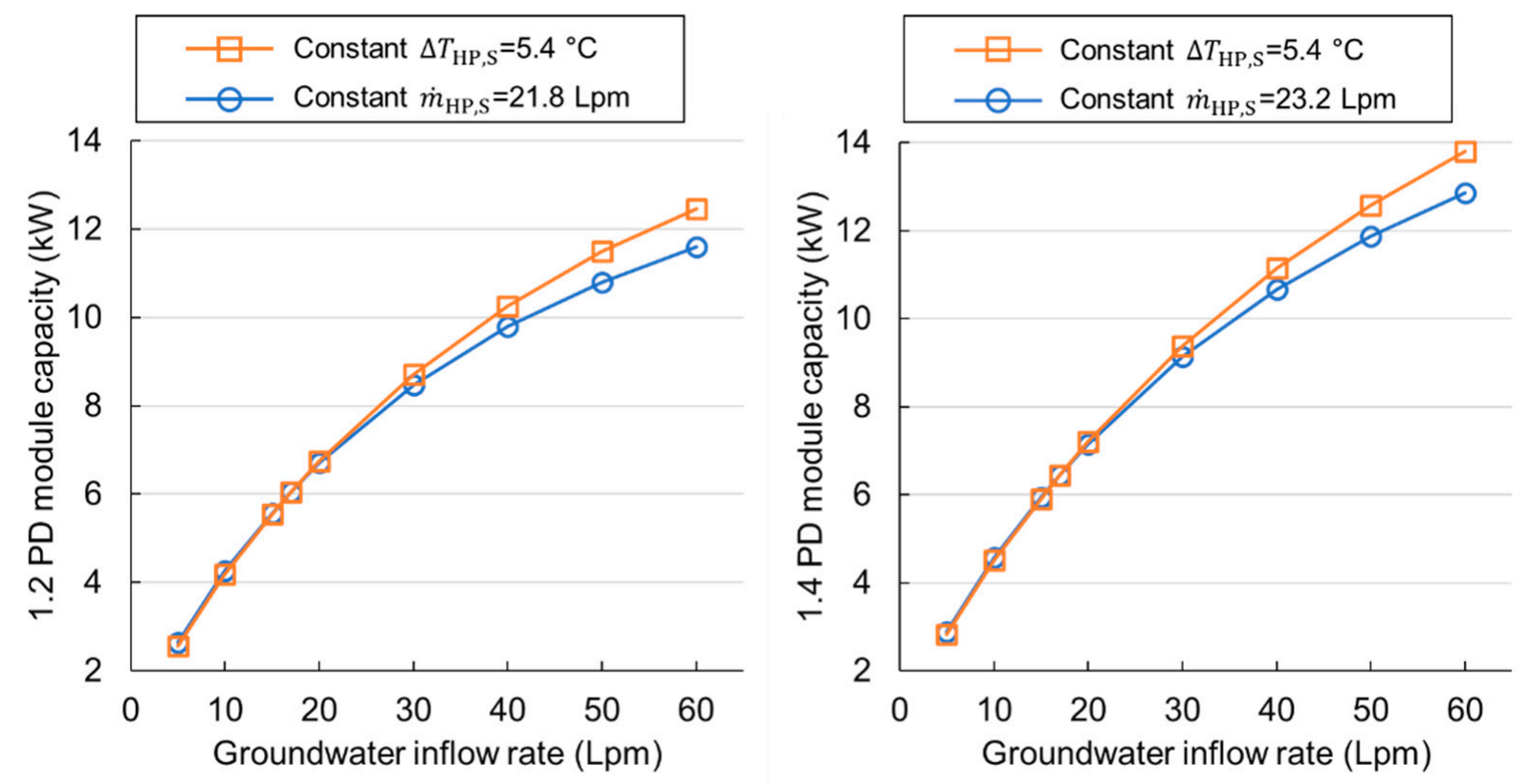

Figure 10. Sizing results for a single 1.2 (left), 1.4 (right) PD module capacity (kW).

Table 6. PD module sizing results for constant $\Delta T_{\mathrm{HP}, \mathrm{S}}(=\mathrm{LST}-\mathrm{EST})$ of $5.4{ }^{\circ} \mathrm{C}$ (marked by a square in Figure 10$)$.

\begin{tabular}{|c|c|c|c|c|c|c|}
\hline $\begin{array}{l}\text { Module Size } \\
\qquad\left(\mathrm{m}^{3}\right)\end{array}$ & $\begin{array}{c}\dot{m}_{\mathrm{GW}, \text { in }} \\
(\mathrm{Lpm})\end{array}$ & $\begin{array}{c}T_{\mathrm{GW}, \text { in }}-T_{\mathrm{GW}, \text { out }} \\
\left({ }^{\circ} \mathrm{C}\right)\end{array}$ & $\begin{array}{l}\dot{m}_{\mathrm{HP}, \mathrm{S}} \\
(\mathrm{Lpm})\end{array}$ & $\begin{array}{c}\Delta T_{\mathrm{HP}, \mathrm{S}} \\
\left({ }^{\circ} \mathrm{C}\right)\end{array}$ & $\begin{array}{c}q_{\text {PDHP }} \\
(\mathrm{kW})\end{array}$ & $\begin{array}{c}\frac{\Delta q_{\mathrm{PDHP}}}{\Delta \dot{m}_{\mathrm{GW}, \mathrm{in}}} \\
(\mathbf{k W / L p m )})\end{array}$ \\
\hline \multirow{8}{*}{$\begin{array}{l}\text { 1.2 PD module } \\
(1.2 \times 1.2 \times 1.5)\end{array}$} & 5 & $20-28.2$ & 9.2 & $35.4-30$ & 2.57 & - \\
\hline & 10 & $20-27.4$ & 15.1 & $35.4-30$ & 4.19 & 0.32 \\
\hline & 15 & $20-26.7$ & 20.0 & $35.4-30$ & 5.55 & 0.27 \\
\hline & 17 & $20-26.5$ & 21.8 & $35.4-30$ & 6.05 & 0.25 \\
\hline & 20 & $20-26.2$ & 24.3 & $35.4-30$ & 6.75 & 0.23 \\
\hline & 30 & $20-25.3$ & 31.4 & $35.4-30$ & 8.72 & 0.20 \\
\hline & 40 & $20-24.7$ & 36.9 & $35.4-30$ & 10.25 & 0.15 \\
\hline & 50 & $20-24.2$ & 41.3 & $35.4-30$ & 11.50 & 0.12 \\
\hline \multirow{8}{*}{$\begin{array}{l}\text { 1.4 PD module } \\
(1.4 \times 1.4 \times 1.5)\end{array}$} & 5 & $20-28.3$ & 10.1 & $35.4-30$ & 2.82 & - \\
\hline & 10 & $20-27.6$ & 16.2 & $35.4-30$ & 4.51 & 0.34 \\
\hline & 15 & $20-27.0$ & 21.3 & $35.4-30$ & 5.91 & 0.28 \\
\hline & 17 & $20-26.8$ & 23.2 & $35.4-30$ & 6.44 & 0.26 \\
\hline & 20 & $20-26.5$ & 25.9 & $35.4-30$ & 7.20 & 0.25 \\
\hline & 30 & $20-25.7$ & 33.7 & $35.4-30$ & 9.38 & 0.22 \\
\hline & 40 & $20-25.1$ & 40.1 & $35.4-30$ & 11.14 & 0.18 \\
\hline & 50 & $20-24.6$ & 45.3 & $35.4-30$ & 12.58 & 0.14 \\
\hline
\end{tabular}


Table 7. PD module sizing results for constant $\dot{m}_{\mathrm{HP}, \mathrm{S}}$ of $21.8 \mathrm{Lpm}$ (1.2 PD module, left), 23.2 Lpm (1.4 PD module, right) (marked by a circle in Figure 10).

\begin{tabular}{|c|c|c|c|c|c|c|}
\hline $\begin{array}{l}\text { Module Size } \\
\qquad\left(\mathrm{m}^{3}\right)\end{array}$ & $\dot{m}_{\mathrm{GW} \text {,in }}$ & $T_{\mathrm{GW}, \text { in }}-T_{\mathrm{GW}, \text { out }}$ & $\dot{m}_{\mathrm{HP}, \mathrm{S}}$ & $\Delta T_{\mathrm{HP}, \mathrm{S}}$ & $q_{\text {PDHP }}$ & $\frac{\Delta q_{\mathrm{PDHP}}}{\Delta \dot{m}_{\mathrm{GW}, \text { in }}}$ \\
\hline & (Lpm) & $\left({ }^{\circ} \mathrm{C}\right)$ & (Lpm) & $\left({ }^{\circ} \mathrm{C}\right)$ & $(\mathrm{kW})$ & (kW/Lpm) \\
\hline & 5 & $20-28.4$ & 21.8 & $32.3-30$ & 2.64 & - \\
\hline & 10 & $20-27.5$ & 21.8 & $33.8-30$ & 4.26 & 0.32 \\
\hline & 15 & $20-26.7$ & 21.8 & $34.9-30$ & 5.58 & 0.26 \\
\hline 1.2 PD module & 17 & $20-26.5$ & 21.8 & $35.4-30$ & 6.05 & 0.24 \\
\hline \multirow[t]{7}{*}{$(1.2 \times 1.2 \times 1.5)$} & 20 & $20-26.1$ & 21.8 & $36.0-30$ & 6.70 & 0.22 \\
\hline & 30 & $20-25.2$ & 21.8 & $37.5-30$ & 8.47 & 0.18 \\
\hline & 40 & $20-24.5$ & 21.8 & $38.8-30$ & 9.80 & 0.13 \\
\hline & 50 & $20-24.0$ & 21.8 & $39.6-30$ & 10.81 & 0.10 \\
\hline & 5 & $20-28.5$ & 23.2 & $32.4-30$ & 2.89 & - \\
\hline & 10 & $20-27.7$ & 23.2 & $33.8-30$ & 4.58 & 0.34 \\
\hline & 15 & $20-27.0$ & 23.2 & $34.9-30$ & 5.94 & 0.27 \\
\hline 1.4 PD module & 17 & $20-26.8$ & 23.2 & $35.4-30$ & 6.44 & 0.25 \\
\hline \multirow[t]{4}{*}{$(1.4 \times 1.4 \times 1.5)$} & 20 & $20-26.5$ & 23.2 & $36.0-30$ & 7.15 & 0.24 \\
\hline & 30 & $20-25.6$ & 23.2 & $37.6-30$ & 9.14 & 0.20 \\
\hline & 40 & $20-24.9$ & 23.2 & $38.9-30$ & 10.67 & 0.15 \\
\hline & 50 & $20-24.4$ & 23.2 & $39.9-30$ & 11.88 & 0.12 \\
\hline
\end{tabular}

As a result, capacities ( $\left.q_{\mathrm{PDHP}}\right)$ of 6.05 and $6.44 \mathrm{~kW}$ were derived when an average groundwater inflow rate $\left(\dot{m}_{\mathrm{GW}, \text { in }}\right)$ of $17 \mathrm{Lpm}$ was applied. The $q_{\mathrm{PDHP}}$ listed in Tables 6 and 7 represents a possible building load that could be covered by the unit

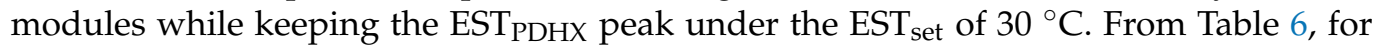
example, the maximum building load should be lower than $6.44 \mathrm{~kW}$ for $\Delta T_{\mathrm{HP}, \mathrm{S}}=5.4{ }^{\circ} \mathrm{C}$ for a single 1.4 PD module with a groundwater inflow rate of $17 \mathrm{Lpm}$. As the container volume of the PD module is increased, the $q_{\text {PDHP }}$ increases as well. Thus, $q_{\text {PDHP }}$ of 1.4 PD module becomes $6.44 \mathrm{~kW}$, which is $0.39 \mathrm{~kW}$ larger than $q_{\mathrm{PDHP}}$ of $1.2 \mathrm{PD}$ module. The single $1.2 \mathrm{PD}$ module can cover a maximum of $12.46 \mathrm{~kW}$, while the $1.4 \mathrm{PD}$ module covers $13.80 \mathrm{~kW}$ with a groundwater inflow rate of up to $60 \mathrm{Lpm}$.

For $\Delta T_{\mathrm{HP}, \mathrm{S}}=5.4{ }^{\circ} \mathrm{C}$, the $\dot{m}_{\mathrm{HP}, \mathrm{S}}$ should be set at 21.8 and $23.2 \mathrm{Lpm}$ for the 1.2 and 1.4 PD modules, respectively. The $q_{\mathrm{PDHP}}$ would vary greatly depending on the variation of $\dot{m}_{\mathrm{GW}, \text { in }}$ rather than the setting of the $\Delta T_{\mathrm{HP}, \mathrm{S}}$ or $\dot{m}_{\mathrm{HP}, \mathrm{S}}$, since the difference in $q_{\mathrm{PDHP}}$ would remain small despite changing $\Delta T_{\mathrm{HP}, \mathrm{S}}$ and $\dot{m}_{\mathrm{HP}, \mathrm{S}}$ under the same $\dot{m}_{\mathrm{GW}}$,in conditions. In the present study, the investigated average rate of groundwater inflow, presented in Table 3 , was used for the set value, $\Delta T_{\mathrm{HP}, \mathrm{S}}=5.4{ }^{\circ} \mathrm{C}$. However, the values of $\dot{m}_{\mathrm{HP}, \mathrm{S}}$ and $\Delta T_{\mathrm{HP}, \mathrm{S}}$ can be determined at the discretion of the designer.

The changes in the capacity of the PD module $\left(\Delta q_{\mathrm{PDHP}}\right)$ corresponding to changing the rate of groundwater inflow $\left(\Delta \dot{m}_{\mathrm{GW}}\right.$,in $)$ by $1 \mathrm{Lpm}$ are presented on the right side of each table. With regard to the $\Delta q_{\mathrm{PDHP}} / \Delta \dot{m}_{\mathrm{GW}}$,in presented in Tables 6 and 7 , the capacity of the 1.4 PD module would increase by an average of $0.34 \mathrm{~kW}$ according to the variation in $\Delta \dot{m}_{\mathrm{GW}, \text { in }}$ by $1 \mathrm{Lpm}$ in the interval of $5-10 \mathrm{Lpm}$, whereas the capacity of the 1.4 PD module increases by an average of $0.27 \mathrm{~kW}$ in the interval of $10-15 \mathrm{Lpm}$.

\subsection{Design of Multiple PDHP System}

Based on the results obtained from Section 4.1, the changes in the capacity of the PDHP system according to the number of modules that were connected in parallel to the source side of the heat pump were analyzed. The groundwater, with a temperature of $20^{\circ} \mathrm{C}$ and flow rate of $17 \mathrm{Lpm}$, was assumed to be flowing into each installed module, while the flow rates on the source side of the heat pump were assumed to be $21.8 \mathrm{Lpm}$ and 23.2 Lpm for the 1.2 module and 1.4 module, respectively.

Figure 11 presents the capacities of the PDHP system corresponding to variable numbers of installed modules (1.2 and 1.4 PD modules). In accordance with increasing the 
number of modules $\left(\mathrm{N}_{\mathrm{PD}}\right)$ and inflow of groundwater $\left(\dot{m}_{\mathrm{GW}, \text { in }}\right)$, the capacity of the PDHP system $\left(q_{\mathrm{PDHP}}\right)$ increases linearly and proportionally. Thus, the respective PDHP systems could be designed by adjusting the capacities of the individual PD modules based this linear relationship and the results presented in Tables 6 and 7.

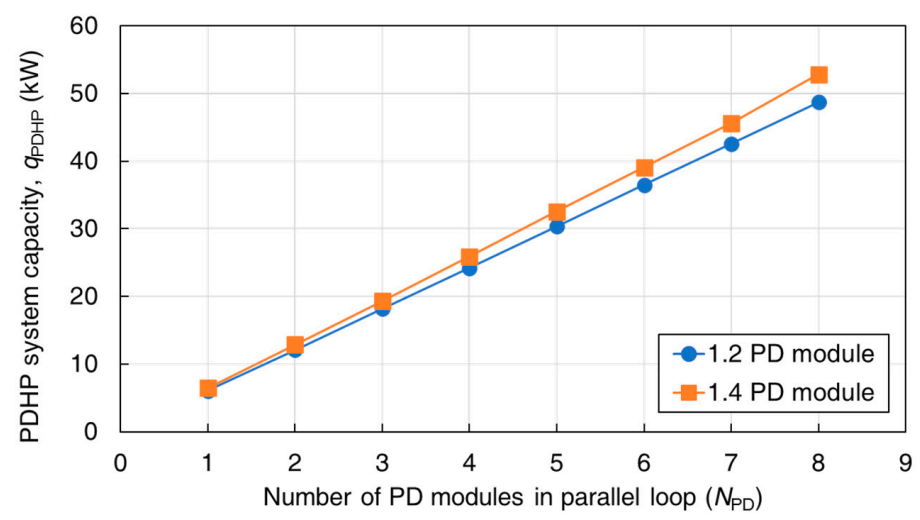

Figure 11. PDHP system capacity according to the number of PD modules in parallel loop.

For instance, the capacity of a single module of $4.5 \mathrm{~kW}$ can be set for a site with the inflow of groundwater of $10.7 \mathrm{Lpm}$ for each PD module in Table 3, which lists the varied groundwater inflow rates at the different sites. Alternatively, a total of 12 PD modules, corresponding to a total inflow rate of $240 \mathrm{Lpm}$ at the $\mathrm{C}$ site, can be installed by assuming that the capacity of each module could accommodate the inflow of $20 \mathrm{Lpm}$ of groundwater. Nevertheless, by referring to the tendencies illustrated in Figure 10, and Tables 6 and 7, the decrease in the increment of $q_{\mathrm{PDHP}}$ according to an increase in $\Delta \dot{m}_{\mathrm{GW} \text {,in }}$ in a single module needs to be taken into account for the combination of PD module designs pertinent to the respective sites.

\subsection{Comparison with an Air Source Heat Pump (ASHP) System}

The comparison results of the annual simulation between the PDHP system with the 1.4 PD module and an ASHP system are shown in Figures 12 and 13 presents the minimum, maximum, and mean COP during June-August (cooling season) and Decemeber-February (heating season), obtained from Figure 12.

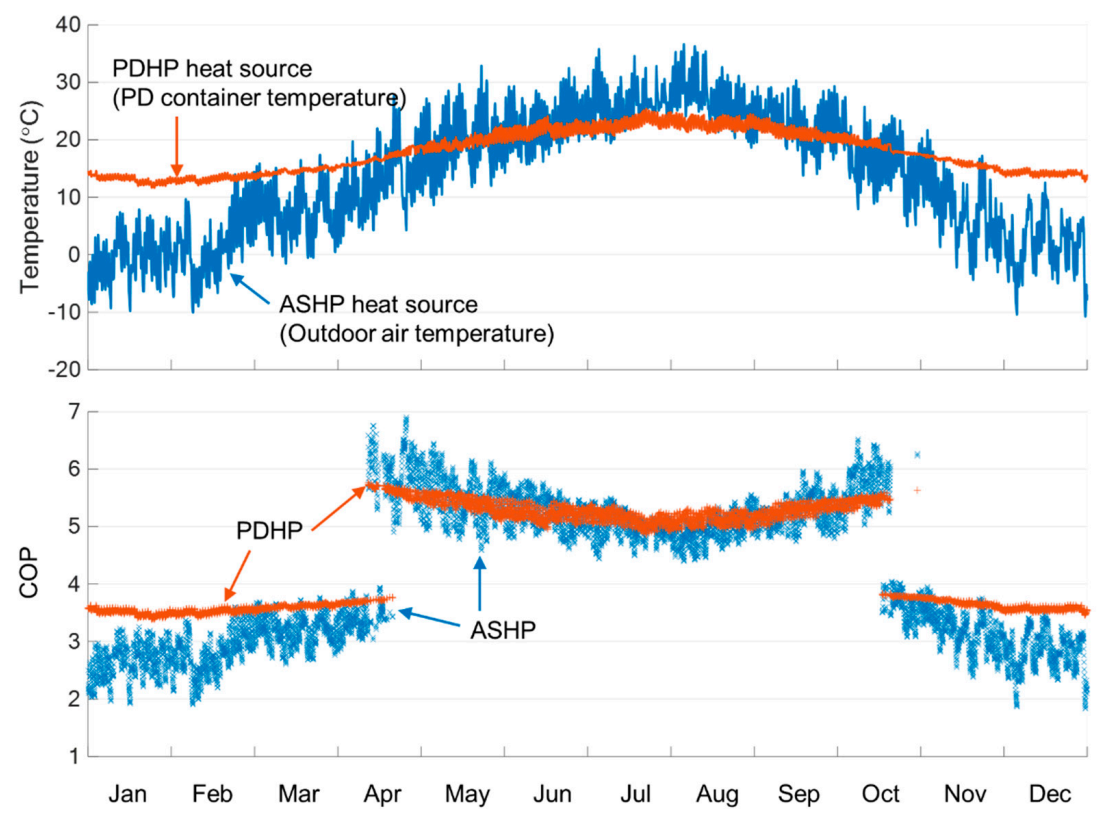

Figure 12. Simulation results of heat pump COPs and heat source temperatures for PDHP and ASHP. 

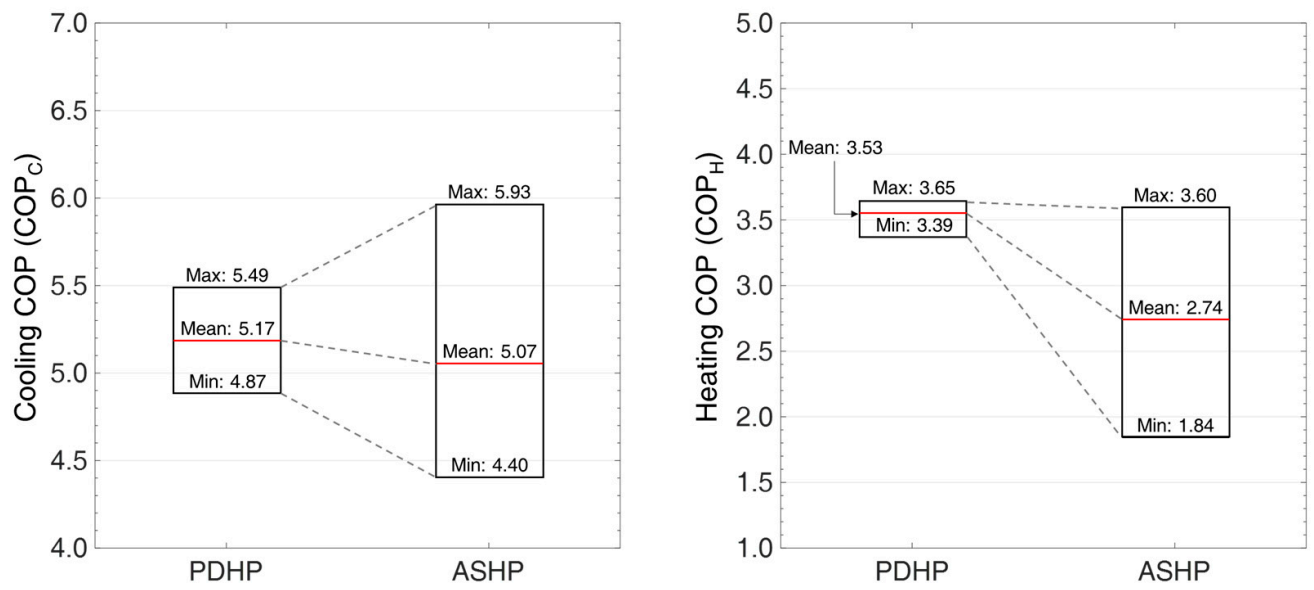

Figure 13. Comparison of cooling and heating COPs of PDHP with ASHP.

In Figure 12, the bottom graph shows the variation in the annual heat source temperatures for the PDHP and ASHP systems, and the top graph shows their COPs, where the heating $\mathrm{COP}\left(\mathrm{COP}_{\mathrm{H}}\right)$ is shown in the lower part from mid-September to mid-March, and cooling $\mathrm{COP}\left(\mathrm{COP}_{\mathrm{C}}\right)$ is shown in the upper portion. The ASHP heat source shows the outdoor air temperature of Seoul, and the PDHP heat source represents the water temperature in the PD container that was simulated in TRNSYS. The groundwater temperature in the PD container (PDHP heat source) is more stable than the outdoor air temperature (ASHP heat source) and is remarkably higher during the heating season. Because the heat pump extracts energy from the heat source during the heating operation, increased source temperatures can drive a higher heat pump COP. Furthermore, a lower source temperature leads to a higher cooling COP because the heat pump injects heat energy into the source. Thus, the heating COP of the PDHP is higher than that of the ASHP, while the cooling COPs are similar.

From Figure 13, the minimum, average, and maximum COP values are presented at the bottom, middle, and top of the boxes, respectively. The average COPs of PDHP are higher than ASHP for both the cooling and heating operations-the PDHP COP ${ }_{C}$ is higher by only 0.1 , while $\mathrm{COPH}$ is higher by 0.79 . Furthermore, the temporal variation according to temperature of outdoor air appears greater than the variation in the temperature of the $\mathrm{PD}$ container, resulting in a more significant variation in the $\mathrm{COP}$ of heating/cooling of the ASHP system than that of PDHP system, which is attributed to the temperature conditions of the heat sources.

The temperature of the PDHP heat source, as shown in the lower portion of Figure 12, remains above $10^{\circ} \mathrm{C}$ in winter, whereas the temperature of the ASHP heat source decreases to $-10{ }^{\circ} \mathrm{C}$, exhibiting a temperature difference of over $20^{\circ} \mathrm{C}$. On the contrary, in the summertime, the temperatures of both heat sources are relatively similar, and the outdoor air temperature occasionally drops below the temperature of the PD container. Thus, the $\mathrm{COP}_{\mathrm{C}}$ for the PDHP, presented in Figure 13, appears similar to that of the ASHP. However, when the system is in operation between 9 a.m. and 6 p.m., the values of $\mathrm{COP}_{\mathrm{C}}$ for the PDHP and ASHP are 5.24 and 4.95, respectively.

The COP of the PDHP system is comparable to that of the ASHP when the temperature of the heat source of the PDHP system is similar to that of the atmosphere. If the PDHP system is used for a building where either the heating load (wintertime) or the cooling load (summertime) is dominant, the performance of the PDHP system, which is superior to that of the ASHP system, could be beneficial. In the present study, the ASHP system and PDHP system were compared using the 'Seoul TRY weather data', however, the differences in both systems would vary according to the usage, design, operation scenarios, and the working fluid of the system $[27,28]$. 


\title{
5. Conclusions
}

Owing to the advancement in technologies of pertinent applications, new and renewable energy sources, such as geothermal energy used in buildings, have been applied to diverse fields worldwide. For example, environmentally friendly low-carbon policies developed for buildings support these applications. However, despite the potential of unrecognized heat sources, in the form of drained or wasted water that could be exploited effectively, in the buildings around us, the institutional devices to utilize these unused energies are yet to be supported by pertinent studies.

In the present study, a permanent dewatering module (PD module) was introduced for the utilization of the abundant water wasted by numerous buildings using underground space in Seoul, and a 'permanent dewatering heat pump (PDHP)' system, exploiting a prototype PD module, was proposed for the utilization of the wasted groundwater. The PD modules of sizes of $1.2 \times 1.2 \times 1.5 \mathrm{~m}$ and $1.4 \times 1.4 \times 1.5 \mathrm{~m}$ can cope with the building loads of $6.05 \mathrm{~kW}$ and $6.45 \mathrm{~kW}$, respectively, at the groundwater inflow rate $17 \mathrm{Lpm}$. The capacity of multiple PD modules, to be exploited as a heat source of a PDHP, increased linearly with increase in the number of modules. Under equivalent conditions, a single PD module of $1.4 \times 1.4 \times 1.5 \mathrm{~m}$ exhibited cooling and heating COPs that were 0.1 and 0.79 higher than those of the ASHP, respectively, which were attributed to the stable temperatures of the heat source.

The results show the potential utilization of the systems for a construction project requiring large-scale underground spaces, where abundant groundwater is available. For such projects, zoning of the PD modules and planning of the heat pump system with adequate PD modules should be considered. Furthermore, the results of the present study can be used for the economic analyses of the PDHP system and the utilization of a hybrid ground source heat pump system.

Author Contributions: Conceptualization, Y.-S.J.; methodology, S.-H.P. and E.-J.K.; software, S.H.P.; validation, S.-H.P. and E.-J.K.; formal analysis, S.-H.P.; investigation, Y.-S.J.; data curation, S.-H.P., Y.-S.J. and E.-J.K.; writing — original draft preparation, S.-H.P.; writing—review and editing, Y.-S.J. and E.-J.K.; Supervision, E.-J.K. All authors have read and agreed to the published version of the manuscript.

Funding: This work was supported by a National Research Foundation of Korea (NRF) grant funded by Korean government (MSIP) (No. 2021R1A2C4002936).

Institutional Review Board Statement: Not applicable.

Informed Consent Statement: Not applicable.

Data Availability Statement: The data used to support the findings of this study are available from the corresponding author upon request.

Acknowledgments: Thanks to GS E\&C for their technical support.

Conflicts of Interest: The authors declare no conflict of interest.

\author{
Abbreviations \\ ASHP Air-source heat pump \\ COP Coefficient of performance \\ EST Entering source-side temperature to heat pump \\ GW Ground water \\ GWHP Ground water heat pump \\ HP Heat pump \\ HX Heat exchanger \\ LST Leaving source-side temperature from heat pump
}




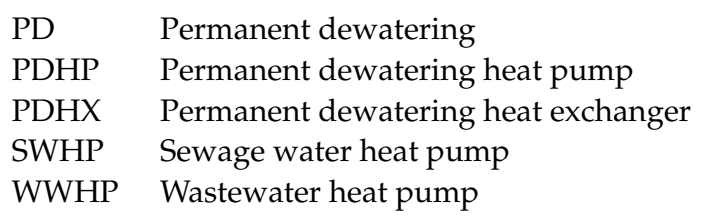

\section{Nomenclatures}

$\begin{array}{ll}\mathrm{COP}_{\mathrm{C}} & \text { Cooling COP }(-) \\ \mathrm{COP}_{\mathrm{H}} & \text { Heating COP }(-) \\ c_{p} & \text { Specific heat }\left(\mathrm{kJ} / \mathrm{kg}^{\circ} \mathrm{C}\right) \\ H_{\text {effective }} & \text { effective height }(\mathrm{m}) \\ \dot{m}_{\mathrm{GW}, \text { in }} & \text { Mass flow rate of ground water inlet }(\mathrm{Lpm}) \\ \dot{m}_{\mathrm{HP}, \mathrm{S}} & \text { Mass flow rate of heat pump source side }(\mathrm{Lpm}) \\ \dot{m}_{\mathrm{PDcoil}} & \text { Mass flow rate of PDHX coil }(\mathrm{Lpm}) \\ N_{\mathrm{PD}} & \text { Number of PD modules }(-) \\ Q_{\mathrm{b}, \text { peak }} & \text { Peak building load }(\mathrm{kW}) \\ Q_{\mathrm{HP}} & \text { Heat pump load }(\mathrm{kW}) \\ q_{\mathrm{PDHP}} & \text { Heat transfer rate of permanent dewatering heat pump }(\mathrm{kW}) \\ T_{\mathrm{GW}, \text { in }} & \text { Ground water inlet temperature }\left({ }^{\circ} \mathrm{C}\right) \\ T_{\mathrm{GW}, \text { out }} & \text { Ground water outlet temperature }\left({ }^{\circ} \mathrm{C}\right) \\ \Delta \dot{m}_{\mathrm{GW}, \text { in }} & \text { Difference in mass flow rate of ground water inlet } \\ \Delta q_{\mathrm{PDHP}} & \text { Difference in heat transfer rate of permanent dewatering heat pump } \\ \Delta T_{\mathrm{HP}, \mathrm{S}} & \text { Temperature difference of heat pump source side, LST-EST }\end{array}$

\section{References}

1. 2019 Global Status Report for Buildings and Construction: Towards a Zero-Emissions, Efficient and Resilient Buildings and Construction Sector. 2019. Available online: https://wedocs.unep.org/handle/20.500.11822/30950?show=full (accessed on 18 April 2021).

2. Langevin, J.; Harris, C.B.; Reyna, J.L. Assessing the Potential to Reduce U.S. Building CO2 Emissions 80\% by 2050. Joule 2019, 3 , 2403-2424. [CrossRef]

3. Radhi, H. Evaluating the potential impact of global warming on the UAE residential buildings-A contribution to reduce the CO2 emissions. Build. Env. 2009, 44, 2451-2462. [CrossRef]

4. Seoul Metropolitan Government. Green Building Design Standard; Seoul Metropolitan Government: Seoul, Korea, 2019.

5. Notaro, V.; Puleo, V.; Fontanazza, C.M.; Sambito, M.; La Loggia, G. A Decision Support Tool for Water and Energy Saving in the Integrated Water System. Procedia Eng. 2015, 119, 1109-1118. [CrossRef]

6. Freni, G.; Sambito, M. Energy Saving and Recovery Measures in Integrated Urban Water Systems. In AIP Conference Proceedings; AIP Publishing LLC: Melville, NY, USA, 2017; Volume 1, p. 190008. [CrossRef]

7. Kastrinos, J.R.; Chiasson, A.; Ormond, P. Estimating groundwater heat exchange in a standing-column well by injection of a bromide tracer. Geothermics 2019, 82, 121-127. [CrossRef]

8. Hervás-Blasco, E.; Navarro-Peris, E.; Corberán, J.M. Closing the residential energy loop: Grey-water heat recovery system for domestic hot water production based on heat pumps. Energy Build. 2020, 216. [CrossRef]

9. Qin, N.; Hao, P.Z. The operation characteristics of sewage source heat pump system and the analysis of its thermal economic benefits. Appl. Therm. Eng. 2017, 124, 1083-1089. [CrossRef]

10. Zhang, Y.; Akkurt, N.; Yuan, J.; Xiao, Z.; Wang, Q.; Gang, W. Study on model uncertainty of water source heat pump and impact on decision making. Energy Build. 2020, 216, 109950. [CrossRef]

11. Cho, Y.; Yun, R. A raw water source heat pump air-conditioning system. Energy Build. 2011, 43, 3068-3073. [CrossRef]

12. Luo, J.; Xue, W.; Shao, H. Thermo-economic comparison of coal-fired boiler-based and groundwater-heat-pump based heating and cooling solution-A case study on a greenhouse in Hubei, China. Energy Build. 2020, 223, 110214. [CrossRef]

13. Song, W.; Ni, L.; Yao, Y. Experimental research on the characteristics of single-well groundwater heat pump systems. Energy Build. 2019, 191, 1-12. [CrossRef]

14. Zhou, X.; Gao, Q.; Chen, X.; Yu, M.; Zhao, X. Numerically simulating the thermal behaviors in groundwater wells of groundwater heat pump. Energy 2013, 61, 240-247. [CrossRef]

15. Shen, C.; Jiang, Y.; Yao, Y.; Wang, X. An experimental comparison of two heat exchangers used in wastewater source heat pump: A novel dry-expansion shell-and-tube evaporator versus a conventional immersed evaporator. Energy 2012, 47, 600-608. [CrossRef]

16. Ferguson, G. Characterizing uncertainty in groundwater-source heating and cooling projects in Manitoba, Canada. Energy 2012, 37, 201-206. [CrossRef]

17. Russo, S.L.; Taddia, G.; Baccino, G.; Verda, V. Different design scenarios related to an open loop groundwater heat pump in a large building: Impact on subsurface and primary energy consumption. Energy Build. 2011, 43, 347-357. [CrossRef] 
18. Nam, Y.; Ooka, R.; Shiba, Y. Development of dual-source hybrid heat pump system using groundwater and air. Energy Build. 2010, 42, 909-916. [CrossRef]

19. Song, J.; Liu, Z.; Ma, Z.; Zhang, J. Experimental investigation of convective heat transfer from sewage in heat exchange pipes and the construction of a fouling resistance-based mathematical model. Energy Build. 2017, 150, 412-420. [CrossRef]

20. Wang, G.; Wang, W.; Luo, J.; Zhang, Y. Assessment of three types of shallow geothermal resources and ground-source heat-pump applications in provincial capitals in the Yangtze River Basin, China. Renew. Sustain. Energy Rev. 2019, 111, 392-421. [CrossRef]

21. Maddah, S.; Goodarzi, M.; Safaei, M.R. Comparative study of the performance of air and geothermal sources of heat pumps cycle operating with various refrigerants and vapor injection. Alex. Eng. J. 2020, 59, 4037-4047. [CrossRef]

22. Yun, S.W.; Choi, H.; Lee, J. Comparison of groundwater levels and groundwater qualities in six megacities of Korea. J. Geol. Soc. Korea 2014, 4036, 517-528. [CrossRef]

23. Klein, S.A. TRNSYS 17: A Transient System Simulation Program; Solar Energy Laboratory University: Madison, WI, USA, 2010.

24. Seoul Metropolitan Government Seoul Water Circulation Information Disclosure System, Secondary Observation Network Data. Available online: http:/ / swo.seoul.go.kr/ugrwtr/retrieveAsstnObsrList.do? (accessed on 25 June 2020).

25. Seoul Metropolitan Government Seoul Water Circulation Information Disclosure System, Discharged Groundwater Data from Buildings. Available online: http:/ / swo.seoul.go.kr/outflow/buildOutList.do?typeNo=02 (accessed on 25 June 2020).

26. Park, S.H.; Kim, E.J. Optimal sizing of irregularly arranged boreholes using duct-storage model. Sustainability 2019, 11, 4338. [CrossRef]

27. Keepaiboon, C.; Dalkilic, A.S.; Mahian, O.; Ahn, H.S.; Wongwises, S.; Mondal, P.K.; Shadloo, M.S. Two-phase flow boiling in a microfluidic channel at high mass flux. Phys. Fluids 2020, 32, 093309. [CrossRef]

28. Deymi-Dashtebayaz, M.; Maddah, S.; Goodarzi, M.; Maddah, O. Investigation of the effect of using various HFC refrigerants in geothermal heat pump with residential heating applications. J. Therm. Anal. 2020, 1-12. [CrossRef] 